\title{
DENDRITIC SUBGLACIAL DRAINAGE SYSTEMS IN COLD GLACIERS FORMED BY CUT-AND-CLOSURE PROCESSES
}

\author{
KATHRIN NAEGELI ${ }^{1,2,4}$, HAROLD LOVELL ${ }^{3,4}$, MICHAEL ZEMP $^{2}$ and DOUGLAS I. BENN ${ }^{4,5}$ \\ ${ }^{1}$ Department of Geosciences, University of Fribourg, Fribourg, Switzerland \\ ${ }^{2}$ Department of Geography, University of Zurich, Zurich, Switzerland \\ ${ }^{3}$ School of Geography, Queen Mary University of London, London, UK \\ ${ }^{4}$ Arctic Geology, The University Centre in Svalbard (UNIS), Longyearbyen, Norway \\ ${ }^{5}$ School of Geography and Geosciences, University of St Andrews, St Andrews, UK
}

\begin{abstract}
Naegeli, K., Lovell, H., Zemp, M. and Benn, D.I. 2014. Dendritic subglacial drainage systems in cold glaciers formed by cut-and-closure processes. Geografiska Annaler: Series A, Physical Geography, 96, 591-608. DoI:10.1111/ geoa. 12059

ABSTRACT. The routing and storage of meltwater and the configuration of drainage systems in glaciers exert a profound influence on glacier behaviour. However, little is known about the hydrological systems of cold glaciers, which form a significant proportion of the total glacier population in the climate sensitive region of the High Arctic. Using glaciospeleological techniques, we obtained direct access to explore and survey three conduit systems and one moulin within the tongue area of Tellbreen, a small cold-based valley glacier in central Spitsbergen. More than $600 \mathrm{~m}$ of conduits were surveyed and mapped in plan, profile and cross-section view to analyse the configuration of the drainage system. The investigations revealed that cold-based glaciers can exhibit a dendritic drainage network with supra-, en- and subglacial components formed most likely by cut-and-closure processes as well as surface-to-bed drainage via moulins. Furthermore, we observed that water is stored within the glacier and released gradually via subglacial conduits during the winter months, forming a large and active icing in the proglacial area The presence of supra-, en- and subglacial components, the surface-to-bed moulin and the dendritic subglacial drainage network suggest that existing models and understanding of the hydrology of cold glaciers needs to be re-evaluated, mostly concerning the different possible pathways and processes that form the hydrological system.
\end{abstract}

Key words: cold glaciers, englacial/subglacial conduit, glacier hydrology, glacio-speleology, icings, Svalbard

\section{Introduction}

Determining the routing of meltwater through glacier systems is of paramount importance as the configuration of drainage networks can have a critical role to play in glacier response to meteoro- logical forcing (cf. Hodgkins 1997) and strongly influence ice dynamics (Röthlisberger and Lang 1987; Irvine-Fynn et al. 2011). Both of these are important factors when considering the near-future contributions of glaciers and ice caps to the global sea-level budgets (Pfeffer et al. 2008; Radić and Hock 2011; Jacob et al. 2012), in addition to more local impacts such as on the hydrology of rivers and the flux of freshwater to fjord environments (Hagen et al. 2003).

The majority of studies have focused on hydrological systems within entirely temperate glaciers and, as a result, hydrological models of drainage pathways within glaciers are typically based on data from temperate glaciers only (e.g. Shreve 1972; Hooke 1989; Nienow et al. 1996; Fountain and Walder 1998; Mair et al. 2003; Fountain et al. 2005; Irvine-Fynn et al. 2011). By contrast, many glaciers in the High Arctic are either entirely cold or polythermal (Hagen et al. 1993) and hence do not fit into existing models of glacier hydrological processes (Gulley et al. 2009a; Irvine-Fynn et al. 2011). Furthermore, the storage and release of water throughout the winter months has typically only been observed at temperate and polythermal glaciers (Liestøl 1976; Gokhman 1987; Hagen et al. 2003). However, studies at Scott Turnerbreen have indicated that predominantly cold polythermal or cold glaciers are also able to store and release water all year round (Hodgkins 1997, 2001; Hodgkins et al. 2004).

Recent developments in glacio-speleology have opened up new opportunities to make direct observations of the formation and complexity of cold and polythermal glacier drainage systems (Pulina 
and Rehak 1991; Vatne 2001; Mavlyudov 2005; Mavlyudov 2006; Badino 2007; Gulley and Benn 2007; Benn et al. 2009a; Gulley et al. 2009a). Glacio-speleological approaches have been applied in Svalbard, North America, the European Alps and the Himalaya (see Table 2 in Gulley et al. 2009b). This work has helped to improve our understanding of meltwater routing processes in temperate, polythermal and cold glaciers (e.g. Gulley et al. 2009a), conduit controls on surging (e.g. Benn et al. 2009b) and hydrofracturing and the formation of moulins (e.g. Benn et al. 2009a; Gulley et al. 2009b). Most recently, Gulley et al. (2012, 2013) used surveys of a subglacial conduit below Rieperbreen, Svalbard, to evaluate conduit roughness values and the interpretation of dye-trace breakthrough curves.

The focus of the present study is the drainage system of Tellbreen, a small valley glacier in central Spitsbergen (Fig. 1). Previous geophysical investigations on Tellbreen by Bælum and Benn (2011) indicated that the glacier is almost entirely cold based. However, a large icing forms in front of the glacier each winter, similar to Scott Turnerbreen, indicating the storage and release of substantial amounts of water within or beneath the glacier. Bælum and Benn (2011) suggested that this apparent contradiction could be explained by the presence of "cut-and-closure conduits", some of which may have reached the bed. The cut-andclosure mechanism of conduit formation involves a two-stage process of channel incision by supraglacial streams followed by roof closure (Gulley et al. 2009a). Deep channels will form and persist wherever channel incision rates exceed glacier surface ablation rates, and roof closure can occur by snow, aufeis or breccia blockages, or wall convergence by ice creep. This is a widespread and dominant process on uncrevassed glacier surfaces in Svalbard and other cold environments, and is a plausible mechanism for forming subglacial conduits beneath thin, cold ice. Glacio-speleology provides the ideal tool to test the groundpenetrating radar (GPR)-based conjecture of Bælum and Benn (2011), by allowing direct access to the drainage system of Tellbreen. Additionally, the analyses of supraglacial, englacial and subglacial sedimentological and glaciological structures provide further information about the formation process and temporal evolution of the drainage system and related implications.

The aims of this study are threefold: to survey the accessible parts of the internal drainage system; to test the hypothesis that subglacial drainage con- duits can form by the cut-and-closure mechanism; and to evaluate the extent to which such systems contribute to the routing, storage and release of water during the winter months.

\section{Study area}

Tellbreen is a land-terminating valley glacier situated at $78^{\circ} 15^{\prime} 15.77^{\prime \prime} \mathrm{N} ; 16^{\circ} 11^{\prime} 17.04^{\prime \prime} \mathrm{E}$ in Helvetiadalen, central Spitsbergen (Fig. 1). At present, Tellbreen is $\sim 4 \mathrm{~km}$ long, $\sim 0.5 \mathrm{~km}$ wide and covers an area of $\sim 2.8 \mathrm{~km}^{2}$ (Bælum and Benn 2011). The glacier ranges in elevation from $\sim 300 \mathrm{~m}$ at the terminus to $950 \mathrm{~m}$ a.s.l., but as the tongue area has a very low gradient, approximately $90 \%$ of the entire glacier surface is situated below $650 \mathrm{~m}$ a.s.l. (Bælum 2006). From the glacier midpoint, the tongue curves towards the southeast and terminates in $\sim 0.5 \mathrm{~km}^{2}$ of ice-cored moraine. The bedrock in the area is composed of readily erodible sandstones, siltstones and shales of the Van Mijenforden and Adventdalen Groups (Hjelle 1993; Dallmann et al. 2002).

GPR data (Bælum 2006; Bælum and Benn 2011) indicate that the glacier is almost entirely below the pressure-melting point and therefore cold based, except for one small and isolated area with potentially warm ice near the base of the thickest $(\sim 100 \mathrm{~m})$ part of the glacier. This is in good agreement with the general understanding of small glaciers on Svalbard having a cold thermal regime (cf. Hagen et al. 1993). Bælum and Benn (2011) calculated a mean ice thickness of $\sim 50 \mathrm{~m}$ in 2009 and where the surveyed conduits are located on the lower tongue a maximum ice thickness of $\sim 30 \mathrm{~m}$ is estimated. Crevassing is restricted to bergschrund areas and isolated open fractures on the lower tongue, which are closely associated with the cave systems investigated in this study (Fig. 1c).

The catchment area of Tellbreen is well defined and characterised by two accumulation basins above $\sim 600 \mathrm{~m}$ a.s.l., which were the only areas with snow cover in August 2011. The equilibrium line altitude of the glacier is unknown, but as the glacier was almost entirely snow-free by August 2011 it is evident that the accumulation area is very limited (cf. Bælum and Benn 2011). The long-term mass balance of Tellbreen over the last $\sim 100$ years since the Little Ice Age (LIA) is calculated to be about $-0.5 \mathrm{~m}$ w.e. $\mathrm{yr}^{-1}$ (Bælum and Benn 2011), which is consistent with the average mass balance for all Svalbard glacier of $-0.55 \mathrm{~m}$ w.e. $\mathrm{yr}^{-1}$ 

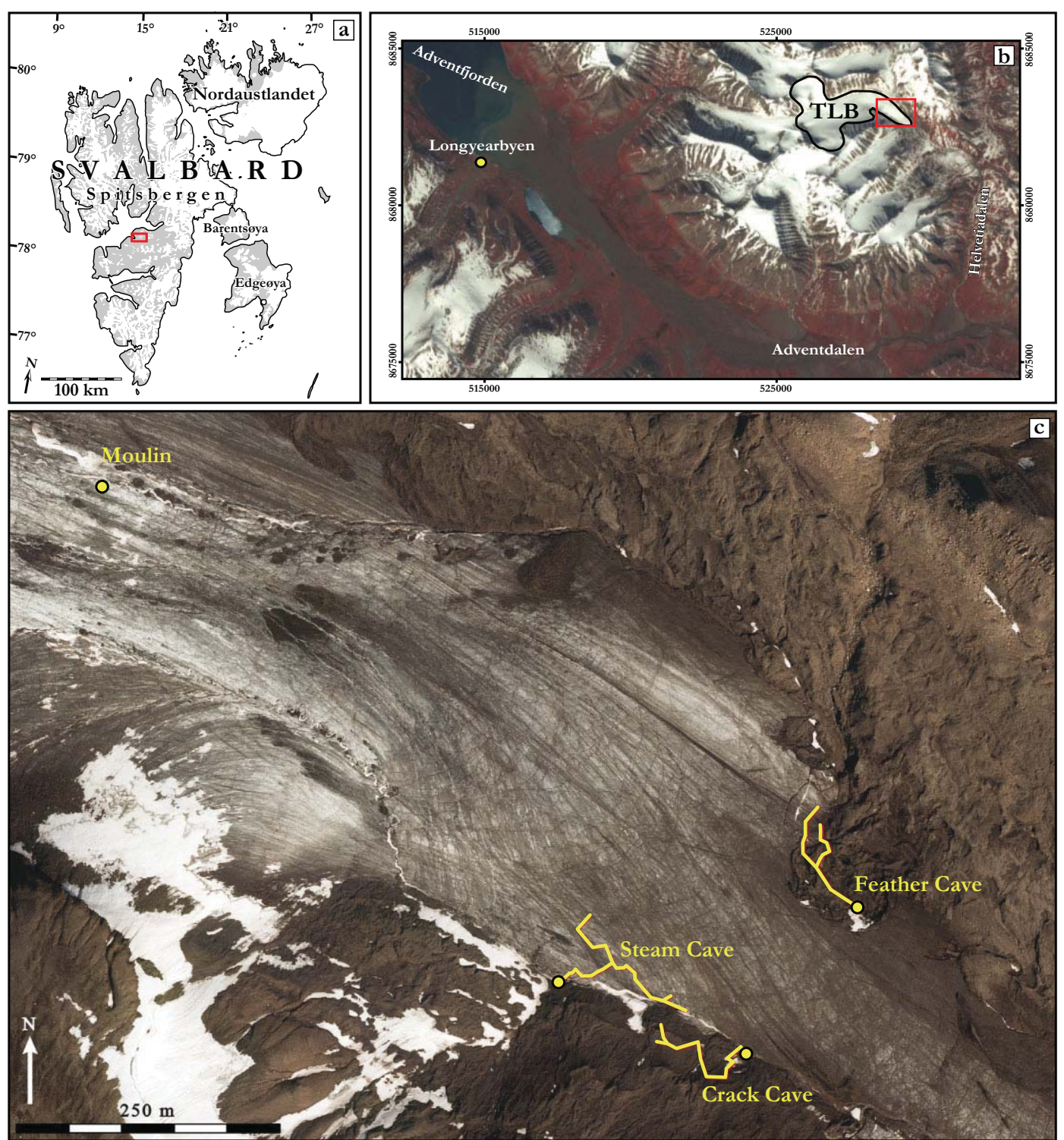

Fig. 1. Location maps. (a) Map of the Svalbard archipelago with the location of Tellbreen marked as a red square. (b) 2001 Landsat ETM+ image showing location of Tellbreen (TLB) relative to Longyearbyen, Adventdalen and Helvetiadalen (provided by USGS Earth Explorer). (c) 2009 NPI aerial photograph of Tellbreen lower tongue (published with the permission of Norsk Polarinstitutt (NPI)). Light yellow lines show location and orientation of the four investigated conduit systems, named Crack cave, Feather cave, Steam cave and Moulin; dots mark the entrance of each system. Feather cave and Crack cave are located within the debris-covered dead ice topography. Please see the online version for this figure in colour.

(Dowdeswell et al. 1997). During this time, Tellbreen has lost $\sim 50 \%$ of its area and $\sim 60 \%$ of its volume and has experienced terminus retreat of $\sim 1 \mathrm{~km}$ (Bælum and Benn 2011). The flow velocity of Tellbreen during recent years is about $1.5 \mathrm{~m} \mathrm{yr}^{-1}$ (C. Bøggild, pers.com. 2012), which can probably be almost entirely attributed to internal deformation (e.g. Etzelmüller et al. 2000).

In the proglacial area a large icing forms each winter, at least partly from water discharging from beneath the glacier (Bælum and Benn 2011). At the glacier front three meltwater conduits can 
be accessed (Fig. 1c), providing an insight into the hydrological system of Tellbreen. Two of them are located in debris-covered dead ice topography southwest and northeast of the clean glacier ice surface (Crack and Feather caves, Fig. 1), while the third is located beneath the clean glacier ice (Steam cave, Fig. 1c). Crack cave is most probably connected with Steam cave and forms the main active channel feeding the proglacial icing.

\section{Methods}

Glacio-speleology is a relatively new and still rather rarely used approach to investigate glacier hydrological systems through the exploration of englacial and subglacial conduits in the winter months (e.g. Vatne 2001; Gulley and Benn 2007; Gulley 2009; Gulley et al. 2009a, 2009b), although it has a long history dating back to the nineteenth century (Forel 1887). In this investigation we use standard speleological techniques adapted for glacier caves (Dasher 1994; Gulley and Benn 2007). All conduit systems were surveyed by producing maps and scale drawings in situ in plan, profile and cross-section view (cf. Gulley et al. 2009a).

The processes of glacio-speleological mapping that were applied to the three conduits located in the lower tongue (Feather, Steam and Crack caves; Fig. 1c) are described in Table 1. Feather cave was discovered and mapped in March 2011; the entrances to Steam and Crack caves and a moulin further upglacier (Fig. 1c) were located and marked in August 2011 prior to being mapped in April 2012. The three investigated conduit systems were mapped using a Leica laser rangefinder for distance measurements and Suunto compass and clinometer for the determination of the azimuth and inclination of the channels. Based on these in situ measurements, geometric parameters such as cave length and depth, mean slope angle and sinuosity ratio were calculated for each conduit system. The cave length and depth is the maximum height difference and length of the route any caver would travel through the cave (Dasher 1994). The overall elevation change with horizontal straight line distance (mean slope angle) and the ratio of the actual path length and the straight line length (sinuosity) help to get a better understanding of the pattern of the conduit system, i.e. whether the system is of meandering character or straight. In addition to these geometric parameters, four main morphology types based on Gulley et al. (2009a) are used to describe
Table 1. Glacio-speleological mapping procedure.

\begin{tabular}{|c|c|}
\hline Stage & Task \\
\hline 1 & $\begin{array}{l}\text { Find potential cave entrances during ablation season, } \\
\text { e.g. where supraglacial meltwater channels } \\
\text { disappear below the glacier surface }\end{array}$ \\
\hline \multirow[t]{2}{*}{2} & $\begin{array}{l}\text { Identify entrances and explore caves during } \\
\text { accumulation season }\end{array}$ \\
\hline & $\begin{array}{l}\text { Important: always consider safety - be aware of } \\
\text { meltwater, instabilities in the ice, instable snow } \\
\text { plugging, etc. }\end{array}$ \\
\hline 3 & Cave mapping: scaled dimensions \\
\hline 3.1 & $\begin{array}{l}\text { Define stations which are: } \\
\text { - representative for a section of the passage } \\
\text { - a maximum of } 20 \text { m apart from each other } \\
\text { visiom both adjacent stations }\end{array}$ \\
\hline 3.2 & $\begin{array}{l}\text { Measurements between two consecutive stations: } \\
\text { - distance } \\
\text { - azimuth } \\
\text { inclination }\end{array}$ \\
\hline 3.3 & $\begin{array}{l}\text { Measurements at each station: } \\
\text { - Dimensions of the passage at that point: up/down } \\
\text { (height) and left/right (width) }\end{array}$ \\
\hline 4 & $\begin{array}{l}\text { Cave mapping: detailed plan, profile and cross-sections } \\
\text { view }\end{array}$ \\
\hline 4.1 & $\begin{array}{l}\text { Sketch the outlines to get a plan and a profile view } \\
\text { map }\end{array}$ \\
\hline 4.2 & $\begin{array}{l}\text { Include observed features in the plan-view map (e.g. } \\
\text { snow, icicles, floor ice structures, rocks, etc.) }\end{array}$ \\
\hline 4.3 & $\begin{array}{l}\text { Sketch cross-sections at each station including } \\
\text { observed features (see 4.2) }\end{array}$ \\
\hline 5 & Complete map \\
\hline & $\begin{array}{l}\text { Draw plan, profile and cross-section view maps } \\
\text { including all recorded details }\end{array}$ \\
\hline 6 & $\begin{array}{l}\text { Calculate geometric parameters: } \\
\text { - Cave length } \\
\text { - Cave depth } \\
\text { - Straight line length } \\
\text { - Mean slope angle } \\
\text { - Sinuosity ratio }\end{array}$ \\
\hline 7 & $\begin{array}{l}\text { Application of additional methods } \\
\text { e.g. ice sampling for isotopic analysis, } \\
\text { glacio-structural measurements, etc. }\end{array}$ \\
\hline
\end{tabular}

the conduit systems. Plugged canyons are defined as relatively narrow, tall passages, with sub-parallel walls, which are either vertical or tilted up towards the centre of meander bends, and their roofs are infilled by snow, aufeis or breccias. Sutured canyons are also relatively narrow and tall, but they are characterised by walls that are brought into contact by ice flow and thus do not show any infillings. Horizontal slots represent wide passages with low roofs, and tubular passages are defined as round or roughly elliptical, formed by re-enlargement of passages by wall-melting.

The mapping technique divides the conduit system into different sections defined by a station at each end. These stations are chosen, numbered and 
marked clearly to ensure an easy recovery throughout the entire mapping period. Furthermore, these stations have to be representative of their section, in order to best recreate the morphology of the conduit. At each of the stations the conduit dimensions as well as the distance, azimuth and inclination to the consecutive stations are determined, resulting in scaled drawings in plan, profile and cross-section view of the entire conduit system. The final maps presented in this paper (cf. Figs 2-4) were drawn using Adobe Illustrator based on the measurements and sketches taken in situ.

Finally, observations of glaciological and sedimentological features (such as glaciofluvial sediments) exposed within the conduit walls and on the glacier surface were recorded, as these can provide an insight into the origin and evolution of the drainage system (Gulley et al. 2009a). Clast shape and fabric data from samples of 50 sandstone clasts were collected and plotted on ternary and stereographic diagrams, respectively. The $\mathrm{C}_{40}$ index (ratio of c/a-axis $\leq 0.4$ ), RA (percentage of very angular and angular clasts) and RWR (percentage of well rounded and rounded clasts) were calculated for the clast shape data following Benn and Ballantyne (1994) and Lukas et al. (2013).

\section{Results}

Geometric parameters and morphology of conduit systems

In total, $636 \mathrm{~m}$ of conduits were mapped in the lower tongue of Tellbreen (Fig. 1c). Within the three systems, 51 stations were marked, recorded and sketched as cross sections. The large moulin observed in the upper area of the tongue was explored but not mapped to the same level of detail as the conduits. The main geometric parameters for the three conduits are shown in Table 2.

Feather cave This cave system was Y-shaped, consisting of a main channel (A) and a side channel (B) (Figs 2a and 5a). The cave was mapped from southeast to northwest, i.e. upglacier from the entrance that was located at $78^{\circ} 15^{\prime} 13.080^{\prime \prime} \mathrm{N} ; 16^{\circ}$ $15^{\prime} 39.960^{\prime \prime}$ E (Fig. 1c). As the cave was open on both sides, airflow through the cave was possible, forming large $(15 \mathrm{~cm})$ ice feathers on the cave roof (Fig. 5b). Channels A and B were $\sim 140 \mathrm{~m}$ and $\sim 60 \mathrm{~m}$ long and, with sinuosity values of 1.2 and 1.3 , relatively straight. The cave descended about $7 \mathrm{~m}$ resulting in a moderate overall inclination (Fig. 2b). From the entrance, which consisted of a large cavern about $20 \mathrm{~m}$ wide and $3 \mathrm{~m}$ high, the channel gradually narrowed and lowered to a width of about $10 \mathrm{~m}$ and a height of about $1 \mathrm{~m}$ at station A5, located about $125 \mathrm{~m}$ inside the channel. The channel was incised into poorly sorted diamict for about $50 \mathrm{~m}$ between station $\mathrm{A} 3$ and A7, interpreted as subglacial traction till [a detailed discussion of the till and the overlying basal and glacier ice is provided by Lovell et al. (in review)]. Side-channel B turned north after about $65 \mathrm{~m}$ from the cave entrance. This channel B was elevated by about $4.5 \mathrm{~m}$ and extended for $60 \mathrm{~m}$ before it was blocked by blown-in snow. The confluence area of channels $\mathrm{A}$ and B was partly filled with fallen ice blocks and at several locations daylight was visible in the roof. In general, the cross sections of channel A were very wide and low, i.e. horizontal slots (Fig. 2a), whereas channel B displayed a tubular morphology (Figs 2a and $5 \mathrm{j}$ ).

Table 2. Geometric parameters for the three investigated cave systems in the lower tongue (see Fig. 1c for locations).

\begin{tabular}{|c|c|c|c|c|c|c|}
\hline \multirow[t]{2}{*}{ Geometric parameter } & \multicolumn{2}{|c|}{ Feather cave } & \multicolumn{2}{|c|}{ Crack cave } & \multicolumn{2}{|c|}{ Steam cave } \\
\hline & $\begin{array}{l}\text { Conduit } \\
\text { Part A } \\
\text { (Stations } \\
\text { A1-A8) }\end{array}$ & $\begin{array}{c}\text { Conduit } \\
\text { Part B } \\
\text { (Stations } \\
\text { A3-B7) }\end{array}$ & $\begin{array}{l}\text { Conduit } \\
\text { Part A } \\
\text { (Stations } \\
\text { A1-Exit) }\end{array}$ & $\begin{array}{l}\text { Conduit } \\
\text { Part B } \\
\text { (Stations } \\
\text { A4-B1a) }\end{array}$ & $\begin{array}{l}\text { Conduit } \\
\text { Part A } \\
\text { (Stations } \\
\text { A1-A18) }\end{array}$ & $\begin{array}{c}\text { Conduit } \\
\text { PartB } \\
\text { (Stations } \\
\text { A11-B4) }\end{array}$ \\
\hline Number of stations & 8 & 7 & 12 & 2 & 18 & 4 \\
\hline Channel length (m) & 139.0 & 57.7 & 145.2 & 19.6 & 157.5 & 79.9 \\
\hline Straight line length (m) & 115.5 & 45.5 & 69.0 & 10.0 & 125.0 & 54.0 \\
\hline Channel depth (m) & 7.5 & 6.2 & 1.1 & 1.1 & 16.3 & 1.4 \\
\hline Mean slope angle & 0.065 & 0.137 & 0.016 & 0.113 & 0.130 & 0.026 \\
\hline Sinuosity & 1.2 & 1.3 & 2.1 & 2.0 & 1.3 & 1.5 \\
\hline Number of stations & \multirow{2}{*}{\multicolumn{2}{|c|}{$\begin{array}{c}15 \\
196.7\end{array}$}} & \multirow{2}{*}{\multicolumn{2}{|c|}{$\begin{array}{c}14 \\
174.9\end{array}$}} & \multirow{2}{*}{\multicolumn{2}{|c|}{$\begin{array}{c}22 \\
264.3\end{array}$}} \\
\hline Cave length (m) & & & & & & \\
\hline
\end{tabular}




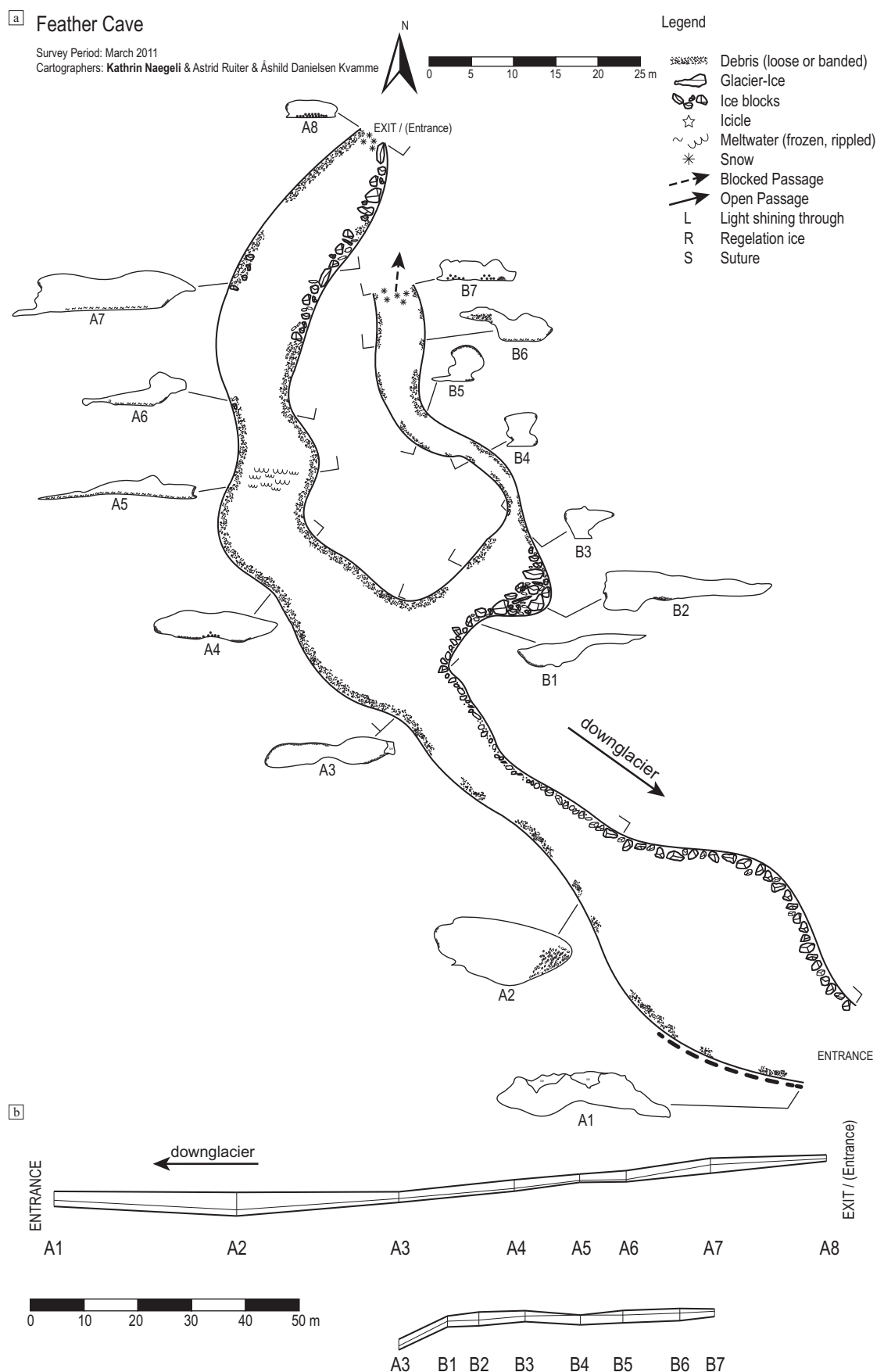

Fig. 2. Feather cave maps. (a) Plan-view map. Dashed line on the left-hand side of the entrance cavern indicates the location of the sediments logged in Fig. 7. (b) Profile-view map showing the two separate branches of the conduit system. Cross sections are drawn at double the size of the plan-view scale. To see all details, especially in the cross sections, please see digital version.. 


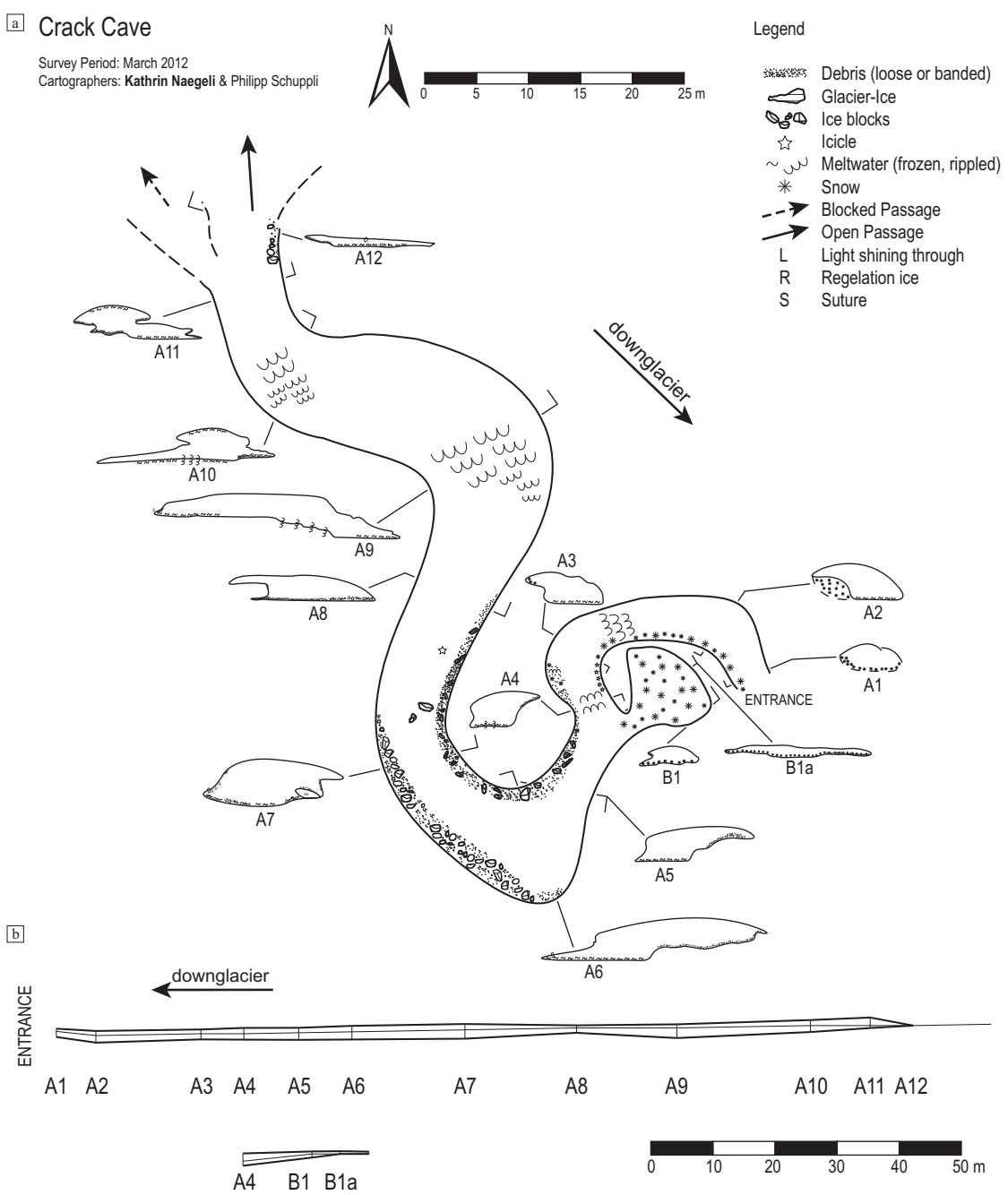

Fig. 3. Crack cave maps. (a) Plan-view map. (b) Profile-view map. Cross sections are drawn at double the size of the plan-view scale. To see all details, especially in the cross sections, please see digital version.

Crack cave This cave was highly sinuous (sinuosity of 2.1) and consisted of a main channel and one small side cavity near the entrance (Fig. 3a). The entrance was located at the southwestern margin of the glacier tongue $\left(78^{\circ} 15^{\prime} 8.640^{\prime \prime} \mathrm{N} ; 16^{\circ} 15^{\prime}\right.$ $22.740^{\prime \prime}$ E; Fig. 1c) and the cave was mapped in an upglacier direction. Channel A was $\sim 145 \mathrm{~m}$ long and had a very low slope, with only 1 m elevation change of the cave floor over this distance (Fig. 3b). The side cavity was $\sim 7 \mathrm{~m}$ by $10 \mathrm{~m}$ across and $\sim 0.5$ to $1 \mathrm{~m}$ high, and was partially blocked by wind-blown snow. Cross sections within the first $40 \mathrm{~m}$ of channel A were primarily tubular in form (Fig. 5c), whereas from station A5 onwards horizontal slots were more common (Fig. 5d). After $\sim 145 \mathrm{~m}$ the conduit dimensions were too constricted to allow further progress. The floor consisted of accumulations of aufeis with some snow in the entrance area and areas of frazil ice and ripple structures were observed further inside the cave. Shortly beyond station A6 the channel was incised into poorly sorted diamict (subglacial till) and the floor was partly to fully covered by loose sediment and rocks (Fig. 5d).

Steam cave This cave had a complex morphology and contained two confluent channels (Fig. 4a). The entrance was located at the point where a lateral supraglacial channel disappeared into the 


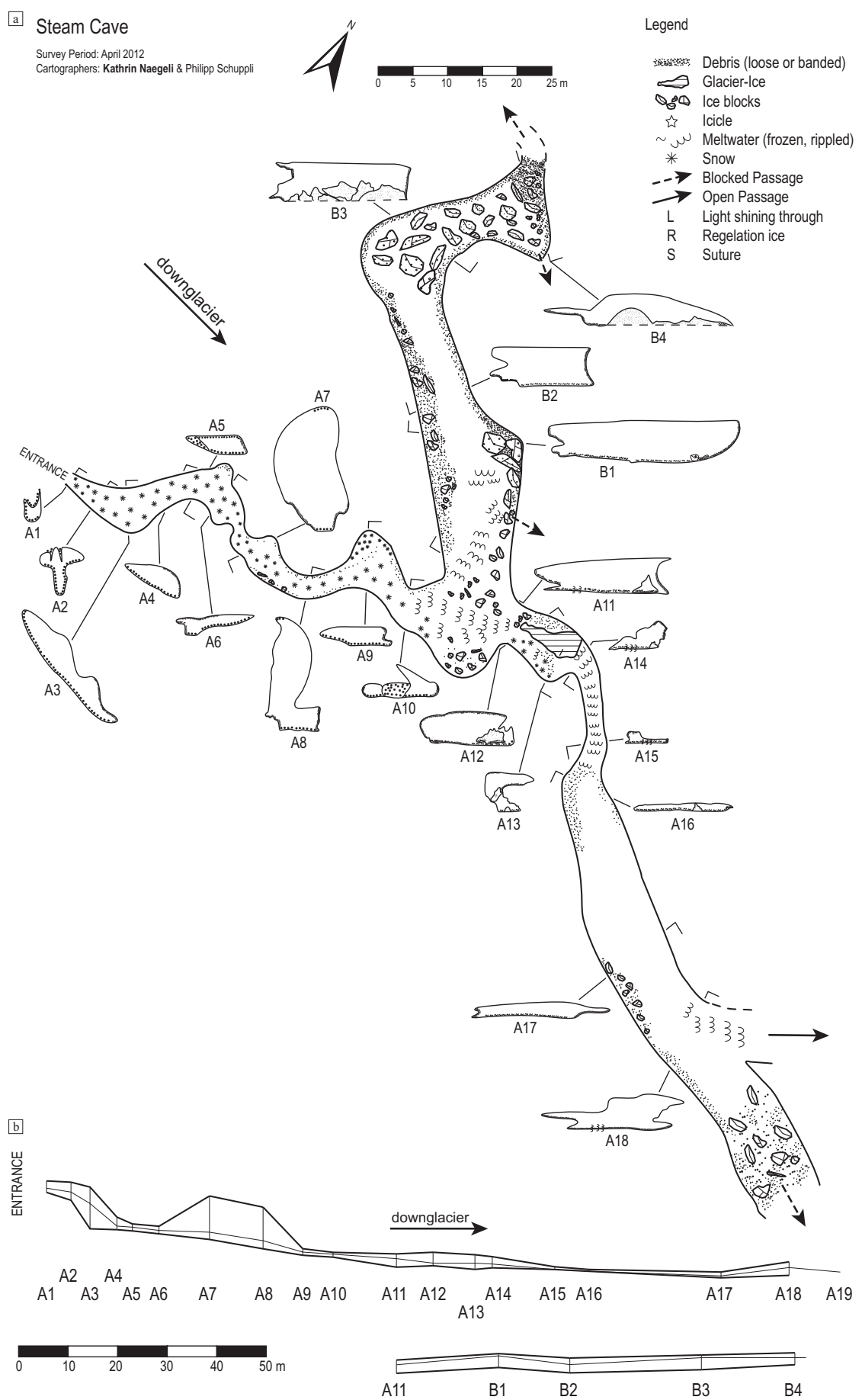

Fig. 4. Steam Cave maps: (a) Plan-view map. (b) Profile-view map showing the two separate branches of the conduit system. Cross-sections are drawn at double the size of the plan-view scale. To see all details, especially in the cross-sections, please see digital version. 
glacier ice (Fig. 5e) at the southwestern margin of

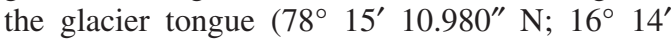
$54.780^{\prime \prime}$ E; Fig. 1c) and the cave was mapped in a downglacier direction. The system consisted of a channel aligned west-east (channel A) and a second channel B aligned northwest-southeast. This cave was the longest measured in Tellbreen, with lengths of $\sim 160 \mathrm{~m}$ and $\sim 80 \mathrm{~m}$ for channel A and B, respectively. The first approximately $50 \mathrm{~m}$ of channel A extending downglacier from the entrance was a relatively narrow and slightly sinuous (sinuousity of 1.3) canyon plugged by snow (cf. cross sections A7 and A8 in Fig. 4a), which widened shortly before the confluence with channel $\mathrm{B}$. The ice within the floor of this confluence zone contained ripple structures. After the confluence, channel A narrowed significantly to a width of only $3 \mathrm{~m}$ and rapidly reduced in height from $3 \mathrm{~m}$ at station $\mathrm{A} 13$ to $0.5 \mathrm{~m}$ at station A16. After station A16 the height of the channel increased again to about $1-2.5 \mathrm{~m}$ and extended over a length of $65 \mathrm{~m}$ until it divided again into two branches. One of the branches was blocked by ice blocks and debris including large boulders, and the floor of the other was too unstable to allow further investigation. The morphology of the cross sections along channel A changed from plugged canyon at the upper end to horizontal slots at the lower end, which were always wide but varied significantly in height $(0.5-2.6 \mathrm{~m})$. In contrast, the cross sections along channel B were all very similar, showing a high width to height ratio (e.g. station B1, 14:3) typical for horizontal slot morphology (Fig. 5f). In the upper part of this channel (from station B3 to B4) the floor was covered by large ice blocks and debris and at the upglacier extent the channel appeared to have been squeezed shut (cf. Gulley et al. 2009a). In the uppermost $16 \mathrm{~m}$ of channel A, the conduit floor is very steep, with an elevation change of about $8 \mathrm{~m}$. Below this, the entire system is gently sloping, demonstrated by the mean slope angle of 0.130 for the entire length of channel A and 0.026 for channel B (Fig. 4b). Both channels were incised into poorly sorted diamict (subglacial till), except for the upper steep part below the entrance. The cave floor was covered by wind-blown snow until station A10, but also contained frazil ice, ripple structures and loose sediment.

Moulin The moulin (Fig. 1c) is located on the northern side of the lower glacier tongue approximately $1.2 \mathrm{~km}$ upglacier from the terminus $\left(78^{\circ} 15^{\prime}\right.$ $26.460^{\prime \prime} \mathrm{N} ; 16^{\circ} 13^{\prime} 47.640^{\prime \prime} \mathrm{E}$; Fig. 1c). The upper
$10 \mathrm{~m}$ of the moulin consisted of a narrow, $\sim 1.5 \mathrm{~m}$ wide bottleneck, after which it opened up to form a $32 \mathrm{~m}$ high and $16 \mathrm{~m}$ wide dome-shaped hall. From the base of the moulin, a very large $(8 \mathrm{~m}$ wide and $12 \mathrm{~m}$ high) $\mathrm{N}$-channel extending downglacier was incised into the sediment and underlying bedrock (Fig. 5g), showing that the moulin connects the glacier surface directly to the bed. A very narrow ( $0.8 \mathrm{~m}$ wide) channel extended upglacier from the base of the moulin, but was blocked by snow after a few meters. The roof of this passage consisted of two separate ice walls that are in contact (Fig. 5i). The N-channel transitioned into a small (1 m wide and $0.5 \mathrm{~m}$ high) $\mathrm{R}$-channel after about $80 \mathrm{~m}$, which continued for approximately $7 \mathrm{~m}$ before it was blocked by boulders and gravel (Fig. 5h).

\section{Glaciological features}

Several unique glaciostructural features were identified within the caves. The flat, disk-shaped bubble structure shown in Fig. 6b was observed in all caves, but mainly in the tubular part of Crack cave. These bubbles were horizontally aligned, easily visible in the clear ice and ranged from few centimetres up to $0.5 \mathrm{~m}$ in diameter. Usually, they were observed in small groups in the conduit roofs, walls and floors. Ripple structures were found within the floors of all caves (Fig. 6d). They extended over distances of a few decimeters up to a few meters, where the floors showed greater slope angles of around $5^{\circ}$. The ripples observed in Crack cave contained frazil ice, whereas others consisted of clear ice. Icicles were found in several places in the conduit systems, such as the one shown in Fig. 6a located between stations A7 and A8 in Crack cave (cf. Fig. 3a). This example bridged between cave roof and floor, covering a height of $0.73 \mathrm{~m}$, and was deformed but showed no fractures. Measured along its length, the icicle is $4 \mathrm{~cm}$ longer than the straight-line distance between roof and floor, indicating that the roof was very slowly closing down after the formation of the icicle at the end of the previous ablation season. Icicles which did not extend the full distance to the cave floor were also commonly observed (Fig. 6c).

\section{Sedimentological features and characteristics}

In several places bands of sorted sediment were exposed in the walls of the conduit systems and at the glacier surface. The englacial exposures primarily consist of sorted sand and gravel, which range in thickness from $\sim 2$ to $150 \mathrm{~cm}$ and can 

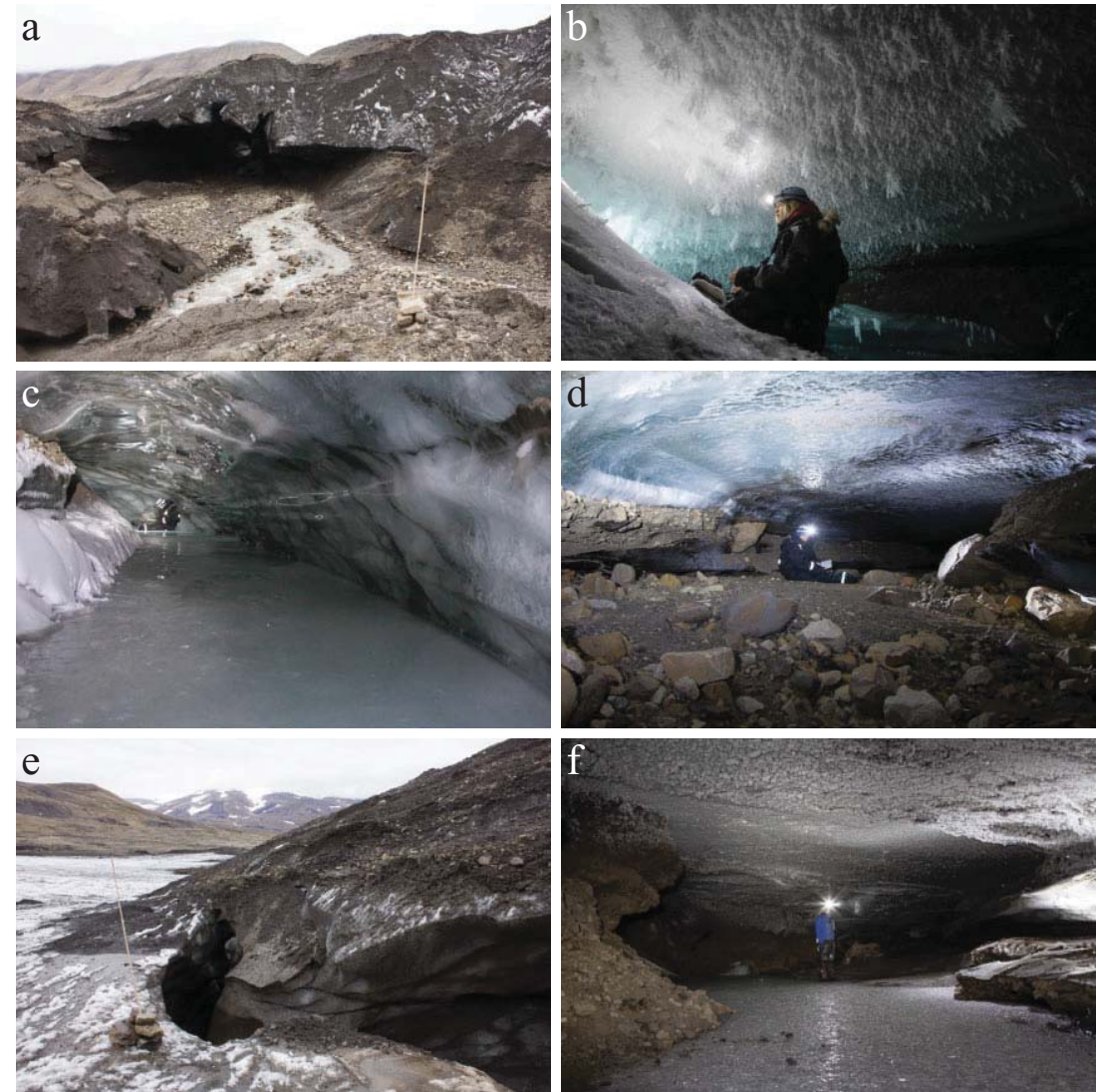

Fig. 5. (a) Feather cave entrance in August 2011. (b) Ice feathers covering the roof of Feather cave. (c) Tubular channel morphology between station A2 and A3 of Crack cave. (d) Horizontal slot passage with floor covered by loose sediment and rocks in Crack cave at station A8. (e) Steam cave entrance in August 2011. (f) Horizontal slot morphology between B2 and B3 of Steam cave. (g) Large $\mathrm{N}$-channel cut down into the poorly sorted diamict below the moulin. (h) Small R-channel incised upwards into the ice at the lowest end of the moulin system. (i) N-channel extending downglacier from the moulin with the two ice walls squeezed together due to ice flow (sutureline). (j) Channel B of Feather cave with infilled sediment band in the wall between station B5 and B6. View is looking down channel. (k) Debris-filled sutures between station A6 and A7 of Crack cave. (Photos taken by K. Naegeli, Ph. Schuppli and E. Welty.)

extend laterally for up to $15 \mathrm{~m}$ (Fig. 6e,h). Figure 7 a shows such an exposure in the entrance cavern of Feather cave (Fig. 2a). Here, a $\sim 2$ thick layer of poorly sorted diamict and the overlying glacier ice are cross cut by layers of sorted fine sand, interbedded sands and gravels and clastsupported massive gravel. The diamict and basal ice sequence are described in detail by Lovell et al. (in review) and are not considered further here. The sorted fine sand layers, which range from 10 to $50 \mathrm{~cm}$ in thickness, display small laminations, which in places record small-scale folding. These layers are overlain by interbedded coarse sands and fine gravels which dip down channel at $\sim 30^{\circ}$ towards the left-hand (downglacier) end of the exposure. Clast-supported coarse gravel layers are also present, the largest of which is $\sim 50 \mathrm{~cm}$ thick and extends for $\sim 6 \mathrm{~m}$. The clasts within these are predominantly sub-angular to sub-rounded (Fig. 7b) and are imbricated, with an orientation of $\sim 000-040^{\circ}$ (Fig. 7c). The sediment band cuts across glaciological structures such as foliation and old crevasse traces, showing that they post-date deformation of the ice. Similar assemblages of sediments were found in debris bands within all caves, some of which extended laterally for several metres along the sidewalls, e.g. in channel B of Feather cave (cf. Fig. 5j). In several places, there 

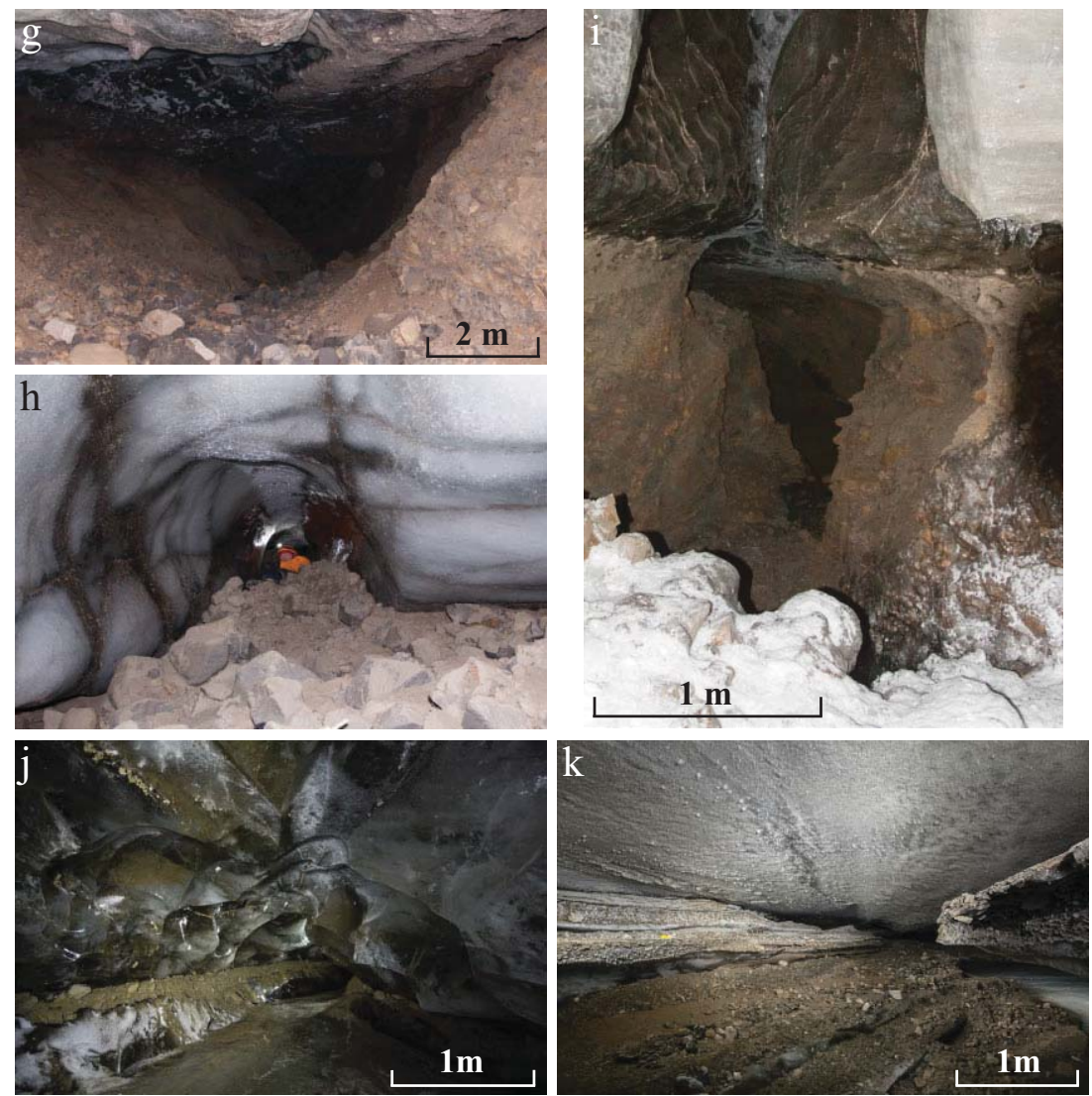

Fig. 5. Continued

are paired debris bands of similar character on opposite walls. In some cases, debris bands can be shown to occupy sutures, where the cave roof and floor have been brought into contact by ice creep. An example between stations A6 and A7 of Crack cave is shown in Fig. 5k. At this site, the cave floor consists of a series of sand and gravel covered terraces, recording vertical and lateral incision of the channel through glacier ice to the bed (top left to bottom right in the photograph). The uppermost terrace is capped by bedded, well sorted sand, the upper surface of which is in contact with the gently sloping cave roof. This contact can be traced laterally up-channel to a series of narrow, open voids between cave floor and roof, and down-channel to sediment layers cutting across the glacier ice, similar to those observed elsewhere.

In August 2011, small ( $\sim 0.5 \mathrm{~m}$ high) piles of coarse sand and fine gravel were observed on the glacier surface (Fig. 6f, g). These were typically located immediately adjacent to incised supraglacial channels in the upglacier part of the lower glacier tongue. The piles were also observed below the glacier surface on shelves within the channel walls and in englacial positions.

\section{Discussion}

\section{Cut-and-closure channel origin}

All three mapped cave systems have englacial and subglacial sections. For example, in Feather cave channel B is entirely located within glacier ice, whereas exposures of basal till occur along much of channel A. Steam cave extends downglacier from a supraglacial channel, into an englacial section with a roof consisting of snow and ice breccia plugs, and finally to subglacial reaches where the channel has incised into basal till. This demonstrates the presence of a surface-fed engla- 

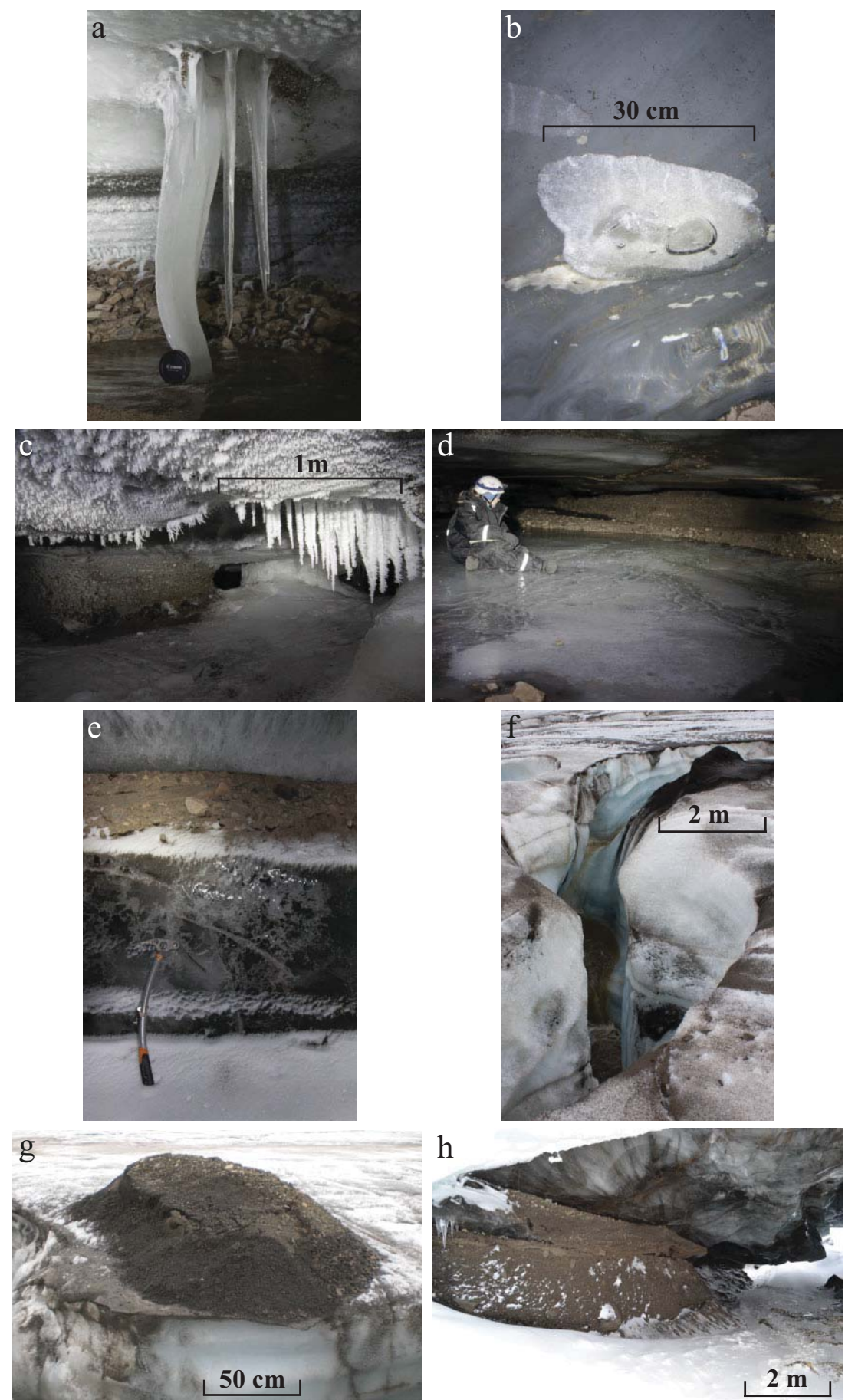

Fig. 6. Glacialogical and sedimentological features found in and around the conduit systems. (a) Deformed icicle within Crack cave between station A7 and A8. (b) Disk-like bubble structure within Crack cave between station A2 and A3. (c) Icicles at station A10 in Steam cave. (d) Ripple structures within the cave floor of Crack cave at station A9. (e) Englacial band of sand and gravel within Crack cave. (f) and (g) Supraglacial piles of sand and fine gravel located adjacent to a meltwater channel. (h) Entrance of Feather cave and the englacial sediment band logged in Fig. 7. (Photos taken by H. Lovell, K. Naegeli and Ph. Schuppli.) 

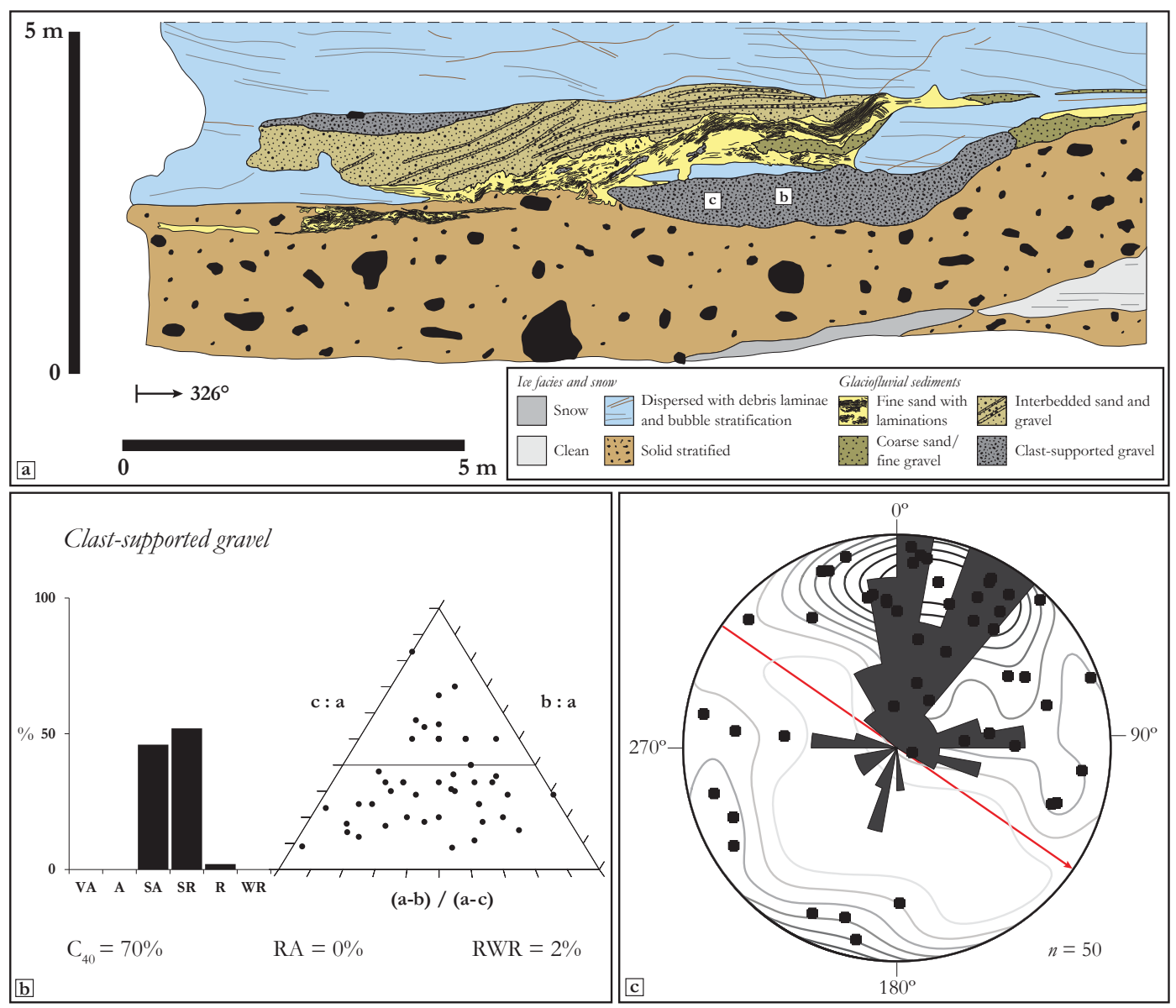

Fig. 7. (a) Log of sediments exposed in the wall of Feather cave (cf. Figs 1c and 2a for location). (b) Clast shape (histogram) and roundness (ternary diagram) data for clast-supported gravel layer (VA = very angular, $\mathrm{A}=$ angular, $\mathrm{SA}=$ sub-angular, $\mathrm{SR}=$ subrounded, $\mathrm{R}=$ rounded, $\mathrm{WR}=$ well rounded; $\mathrm{a}, \mathrm{b}$ and $\mathrm{c}=\mathrm{long}$, intermediate and short orthogonal axes of each particle respectively). (c) Lower hemisphere equal-area stereographic projection and rose diagram of clast fabric data taken from clast-supported gravel layer. (Red arrow indicates ice flow direction.) Sample locations are marked on (a). For more explanation, see text "sedimentological features". Please see the online version for this figure in colour..

cial and subglacial drainage network, as suggested by Bælum and Benn (2011) based on GPR data.

The bands of sorted sediments exposed in the walls of all three caves are interpreted as suture infills of glaciofluvial material, where cave roofs came into contact with former channel floors, sealing off the upper, older levels of the system. This is most clearly demonstrated in the reach of Crack cave shown in Figure 5k. In the other caves, the cross-cutting relationship between the sediment bands and glaciological structures such as ice foliation supports the conclusion that all the subglacial reaches formed by the process of cutand-closure.
Altogether, these observations provide strong evidence that the three conduit systems were formed by a cut-and-closure process, in which supraglacial channels progressively developed into plugged canyons with roofs of snow and aufeis, then sutured canyons closed by ice creep, and finally to horizontal slots and N-channels at the glacier bed with sediment-filled sutures at their lateral margins. Furthermore, the moulin clearly shows that surface to bed drainage is possible in cold ice.

The roof of the large channel extending downglacier from the bottom of the moulin consists of glacier ice and the floor was deeply incised into the glacier bed. Moreover, the roof showed a clear 
suture line (Fig. 5i), which formed when two ice walls squeezed together due to ice flow. We therefore infer that this large N-channel also evolved from a former incised supraglacial channel.

The branching planforms of both Feather and Steam caves provides the first evidence for dendritic channel systems at the bed of cold glaciers. All other recorded cases of subglacial channels below small glaciers in Svalbard consist of single, unbranching conduits (e.g. Longyearbreen: Humlum et al. 2005; Van Hoof 2008; Scott Turnerbreen: Temminghoff 2009; and Rieperbreen: Gulley et al. 2012, 2013). The existence of dendritic subglacial channel networks, which likely evolved from branching supraglacial channels, suggests that surface water may be able to access significant parts of the bed of cold glaciers, at least where the ice thickness is thin.

\section{Water flow and storage within the drainage system}

Bælum and Benn (2011) interpreted localized GPR reflections as evidence of water below the lower glacier tongue of Tellbreen and hypothesised that this water was restricted to discrete channels. They concluded that warm-based conditions were not necessary for the presence of water flow beneath glaciers in the winter months and, therefore, that subglacial water storage cannot be directly linked to subglacial water production. This is supported by the observations of our study, in which water flow was clearly audible in April 2012 and also visible in the form of wet and slushy cave floors. Furthermore, most of the ice-floored channels consisted of refrozen meltwater, often containing frozen ripple structures, rather than glacier ice, which typically takes the form of intercalated layers of bubble-rich and bubble-poor ice (cf. Hubbard et al. 2000).

The different morphologies of the channels provide information about the water level in the past. Tubular channel shapes, as observed in the lowermost $40 \mathrm{~m}$ of Crack cave and the full length of channel B in Feather cave, form under constricted, transient phreatic (epiphreatic; Gulley et al. 2009a) conditions during periods of high meltwater discharge, when channels are enlarged by wall melting. Pipe-full discharge therefore occurred at some point in the formation of these caves. In addition, the disk-like bubble structures, mostly observed within sections with a tubular morphology, most probably form under phreatic (pipe-full; Gulley et al. 2009a) conditions, when dissolved gases accumulate during the slow freezing of the ice, forming gas occlusions (Lorrain et al. 2002; Boereboom et al. 2012).

Figure 8 illustrates the water pathways observed in Tellbreen as a conceptual model showing the suggested evolution of the hydrological system of cold valley glaciers on Svalbard. The model stages (a)-(f) present both temporal and spatial evolution of the drainage system. Stage (a) shows a section of a glacier located in the upper tongue area. Meltwater in this area is mainly routed within supraglacial channels. As discharges increase downglacier, incision rates exceed ablation rates in the adjacent ice, leading to progressive channel deepening (Gulley et al. 2009a). Former bedload of the stream can be stored in upper, abandoned levels of the channels, and later melt out forming piles of glaciofluvial sediments on the glacier surface (stage (d) and (e); cf. Fig. 6f, g). In addition, moulins can be present that route meltwater directly from the surface to the glacier bed.

The supraglacial channel in stage (a) is still fully open, and stage (b) indicates the progressive plugging by snow, aufeis and ice breccias created by collapses (Gulley et al. 2009a). In stage (c), the channel is already partly closed and plugging continues at the glacier surface. Further downglacier, but also at a later time-step, this partly closed channel is completely disconnected from the surface and is a fully englacial channel (stage (d)). In addition, abandoned meander fills can be observed on the glacier surface from the earlier active supraglacial channel. In the lower tongue, these englacial channels usually incise down to the glacier bed. Here, the meltwater can either erode into subglacial sediments or bedrock, i.e. an $\mathrm{N}$-channel (stage (e)), or be incised up into the ice, i.e. an R-channel (stage (f)). The dendritic form of the subglacial channel network is inherited from former confluent supraglacial streams. Stage (f) also shows the proglacial area, including streams exiting the glacier through portals and, in winter months, forming proglacial icings.

\section{Implications for existing glacier hydrological theories}

Many glacier hydrological studies have focused on topics such as meltwater flow over different types of beds (e.g. Röthlisberger 1972; Kamb 1987; Walder and Fowler 1994) or pathways and routing of meltwater within and beneath the ice body (e.g. Tranter 


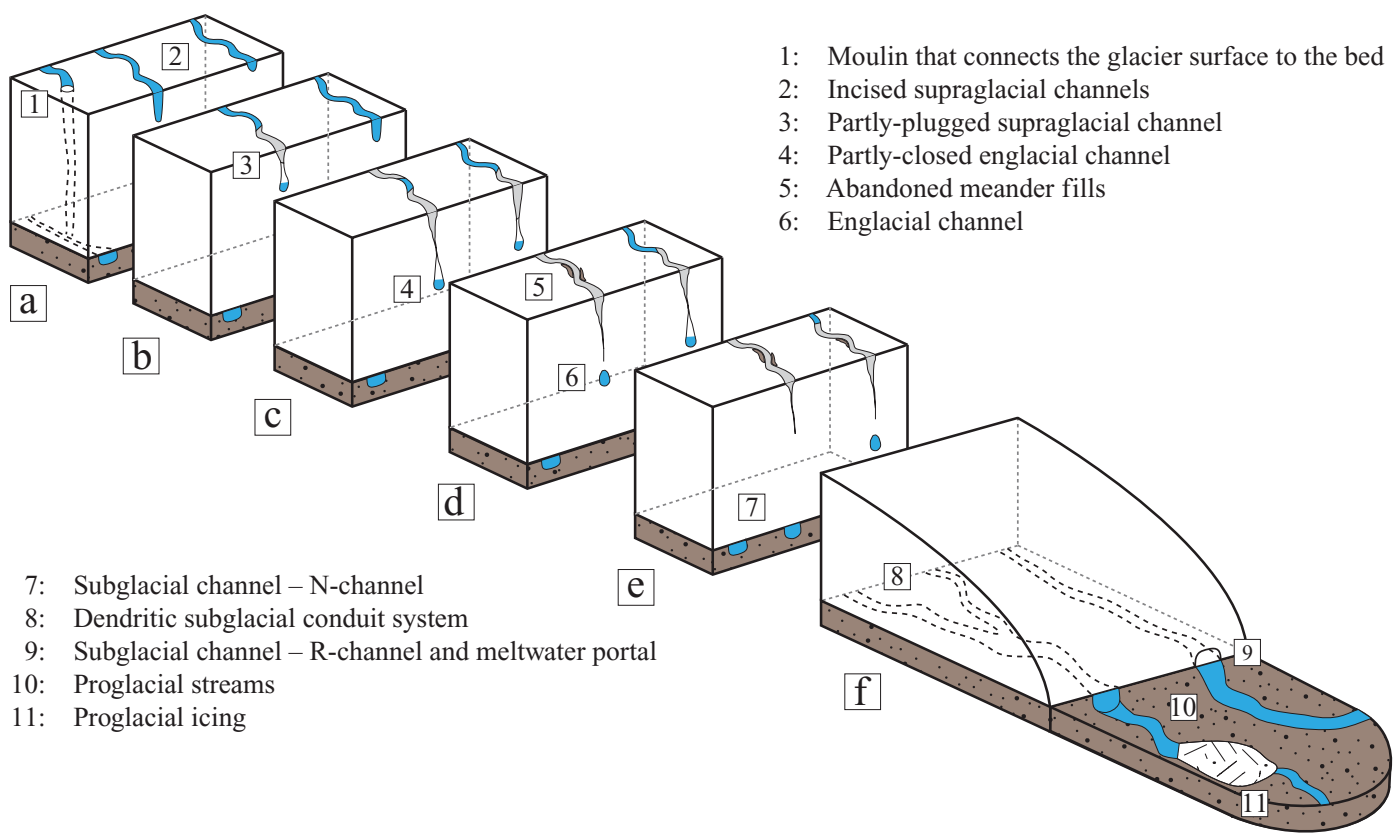

Fig. 8. Conceptual diagram of the temporal and spatial evolution (stage a-f) of the drainage system within cold valley glaciers. For more explanation, see text. Please see the online version for this figure in colour.

et al. 1996; Fountain and Walder 1998; Fountain et al. 2005). Many conceptual models are largely based only on temperate glaciers, and, to a lesser extent, polythermal glaciers (Gulley et al. 2009b; Irvine-Fynn et al. 2011). Comparable studies of cold glaciers are, however, almost completely lacking. Nevertheless, in recent years new conceptual ideas have arisen about water routing in glacier ice and it is now widely recognized that hydrofracturing (e.g. Boon and Sharp 2003; Benn et al. 2009a) and the exploitation of permeable structures (e.g. Gulley et al. 2009b) are efficient processes that are able to route water through cold ice. Furthermore, the process of cut-and-closure has been observed on glaciers with partly or entirely cold ice, and this is therefore a third mechanism that is capable of creating supra-, en- and subglacial drainage networks in cold glaciers (Gulley et al. 2009a). This latter mechanism is strongly supported by the observations at Tellbreen. There is no evidence that any of the drainage systems we have observed have evolved from relict 'Shreve-type' conduits, formed normal to equipotential surfaces in permeable temperate ice (Shreve, 1972) as suggested in some previous studies (Hodgkins 1997; Stuart et al. 2003).
Moreover, drainage systems within cold glaciers were conventionally suggested to have a simple configuration, as drainage was assumed to be restricted to surface runoff (cf. Hodgkins 1997). The evidence from Tellbreen demonstrates that the conduit drainage system within cold glaciers can in fact be dendritic, reflecting the temporal and spatial evolution of channels through cut-and-closure processes.

Icings form by the refreezing of gradually released meltwater throughout the winter months (Irvine-Fynn et al. 2011) and were for a long time believed to be a clear indicator of a polythermal regime of the glacier (Liestøl 1976; Gokhman 1987; Hagen et al. 2003). More recent studies conducted at Scott Turnerbreen (Hodgkins 2001; Hodgkins et al. 2004), a similar-sized valley glacier to Tellbreen and also consisting of predominantly cold ice, questioned this strict link between icings and temperate or polythermal glaciers, although the question as to how water could be stored within cold glaciers remained unanswered. The detailed investigations of the three conduits systems in the lower tongue and the presence of a large and active icing in the front of Tellbreen during Spring demonstrate that water stored 
beneath Tellbreen can be released during the winter months via subglacial conduits. The origin of this water, however, remains unknown.

The fact that a cold-based glacier like Tellbreen apparently experiences year round water storage and flux also implies that the erosional capability and solute flux below cold glaciers such as Tellbreen is greater than previously assumed. As seen from this study, cold glaciers may be capable of storing and releasing water year round and should therefore be considered as an active component in the hydrological cycle and its seasonal distribution and response to meteorological forcing.

\section{Conclusions}

The systematic glacio-speleological investigation of three conduit systems and a moulin in the tongue area of Tellbreen, an predominantly cold glacier in Svalbard, provide an insight into the hydrological systems of cold-based valley glaciers. This shows that glacio-speleology is a powerful technique to improve the understanding of glacier hydrology and enables the exploration of englacial and subglacial components of the drainage system.

The drainage systems of cold valley glaciers can be dendritic and have supra-, en- and subglacial components. Water can also be routed directly from the glacier surface to the bed via moulins. Cut-and-closure is an effective process for forming drainage systems within cold glaciers and results in a transition from supraglacial channels in the upper ablation area to englacial and subglacial channels in the lower ablation area. Proglacial icings in front of cold glaciers can be directly linked to water released from the glacier and transported via subglacial channels.

The observations and results presented in this paper suggest that current concepts about glacier drainage systems in cold glaciers need reevaluation, specifically concerning the different possible pathways, processes forming the conduits and capability of storing and releasing water.

\section{Acknowledgement}

KN was funded by an Arctic Field Grant from the Research Council of Norway, the Swiss Society for Speleology and the travel grant commission of the Swiss Academy of Science. HL was funded by a NERC PhD studentship (NE/I528050/1), the Queen Mary Postgraduate Research Fund and an Arctic Field Grant from the Research Council of
Norway. Landsat satellite images were provided by USGS Earth Explorer and aerial photographs were acquired from the Norsk Polarinstitutt. Fieldwork support from the Logisitics Department of the University Centre in Svalbard was vital and we are grateful to E. Fleming, B. Hubbard, N. Hulton and Ph. Schuppli for their contributions to the collection of field data, and to all members of AG-325 in 2011, who were present when the cave systems of Tellbreen were first discovered. The photograph reproduced in Figure 5k was taken by E. Welty. We thank W. Haeberli for the stimulating discussion of the glaciological features and M. Huss, L. Sold, M. Fischer and two anonymous reviewers for their detailed and thoughtful manuscript review.

Kathrin Naegeli, Department of Geosciences, University of Fribourg, Chemin de Musée 4, 1700 Fribourg, Switzerland E-mail: kathrin.naegeli@unifr.ch

Harold Lovell, Department of Geography, University of Portsmouth, Buckingham Building, Lion Terrace, Portsmouth PO1 3HE, UK

E-mail: harold.lovell@port.ac.uk

Michael Zemp, Department of Geography, University of Zurich - Irchel, Winterthurerstrasse 190, 8057 Zürich, Switzerland

E-mail: michael.zemp@geo.uzh.ch

Douglas I. Benn, Arctic Geology, The University Centre in Svalbard (UNIS), PO Box 156, N-9171 Longyearbyen, Norway

E-mail: doug.benn@unis.no

\section{References}

Badino, G., 2007. Caves of Sky: A Journey into the Heart of Glaciers. Graffice Tintoretto, Italy. 154 p.

Bælum, K., 2006. Mapping of the general shape, depth and various internal structures of Tellbreen, a glacier on Svalbard, by means of GPR (Ground Penetrating Radar). MS diss., Department of Geoscience, University of Arhus, Denmark.

Bælum, K. and Benn, D.I., 2011. Thermal structure and drainage system of a small valley glacier (Tellbreen, Svalbard), investigated by ground penetrating radar. The Cryosphere, 5, 139-149. doi:10.5194/tc-5-139-2011

Benn, D.I. and Ballantyne, C.K., 1994. Reconstructing the transport history of glacigenic sediments: a new approach based on the co-variance of clast form indices. Sedimentary Geology, 91, 215-227. doi:10.1016/00370738(94)90130-9

Benn, D.I., Gulley, J.D., Luckman, A., Adamek, A. and Glowacki, P.S., 2009a. Englacial drainage systems formed by hydrologically driven crevasse propagation. Journal of Glaciology, 55 (191), 513-523. doi:10.3189/ 002214309788816669 
Benn, D.I., Kristensen, L. and Gulley, J.D., 2009b. Surge propagation constrained by a persistent subglacial conduit, Bakaninbreen - Paulabreen, Svalbard. Annals of Glaciology, 50 (52), 81-86. doi:10.3189/ 172756409789624337

Boereboom, T., Depoorter, M., Coppens, S. and Tison, J.-L., 2012. Gas properties of winter lake ice in Northern Sweden: implication for carbon gas release. Biogeosciences, 9, 827-838. doi:10.5194/bg-9-827-2012

Boon, S. and Sharp, M., 2003. The role of hydrologicallydriven ice fracture in drainage system evolution on an Arctic glacier. Geophysical Research Letters, 30 (18), 1-4. doi:10.1029/2003GL018034

Dallmann, W.K., Ohta, Y., Elvevold, S. and Blomeier, D., 2002. Bedrock map of Svalbard and Jan Mayen, Norsk Polarinstitutt Temakart No. 33

Dasher, G.R., 1994. On Station. National Speleological Society, Inc., Huntsville.

Dowdeswell, J.A., Hagen, J.O., Björnsson, H., Glazovsky, A.F., Harrison, W.D., Holmlund, P., Jania, J., Koerner, R.M., Lefauconnier, B., Ommanney, C.S.L. and Thomas, R.H., 1997. The mass balance of circum-Arctic glaciers and recent climate change. Quaternary Research, 48, 1-14. doi:10.1006/qres.1997.1900

Etzelmüller, B., Ødegård, R.S., Vatne, G., Mysterud, R.S and Sollid, J.L., 2000. Glacier characteristics and sediment transfer system of Longyearbreen and Larsbreen, western Spitsbergen. Norwegian Journal of Geography, 54 (4), 157-168. doi:10.1080/002919500448530

Forel, M.F.-A., 1887. La grotte naturelle du glacier d'Arolla. Archives des sciences physiques et naturelles.

Fountain, A.G., Jacobel, R.W., Schlichting, R. and Jansson, P., 2005. Fractures as the main pathways of water flow in temperate glaciers. Nature, 433 (7026), 618-621. doi:10.1038/nature03296

Fountain, A.G. and Walder, J.S., 1998. Water flow through temperate galciers. Reviews of Geophysics, 36, 299-328. doi:10.1029/97RG03579

Gokhman, V.V., 1987. Distribution and conditions of formation of glacial icings on Spitsbergen. Polar Geography and Geology, 11 (4), 249-260. doi:10.1080/ 10889378709377334

Gulley, J.D., 2009. Structural control of englacial conduits in the temperate Matanuska Glacier, Alaska, USA. Journal of Glaciology, 55 (192), 681-690. doi: 10.3189/ 002214309789470860

Gulley, J.D. and Benn, D.I., 2007. Structural control of englacial drainage systems in Himalayan debris-covered glaciers. Journal of Glaciology, 53 (182), 399-412. doi:10.3189/002214307783258378

Gulley, J.D., Benn, D.I., Müller, D. and Luckman, A 2009a. A cut-and-closure origin for englacial conduits in uncrevassed regions of polythermal glaciers. Journal of Glaciology, 55 (189), 66-80. doi: 10.3189/ 002214309788608930

Gulley, J.D., Benn, D.I., Screaton, E. and Martin, J., 2009b Mechanisms of englacial conduit formation and their implications for subglacial recharge. Quaternary Science Reviews, 28, 1984-1999. doi:10.1016/j.quascirev.2009 04.002

Gulley, J.D., Spellman, P.D., Covington, M.D., Martin, J.B., Benn, D.I. and Catania, G., 2013. Large values of hydraulic roughness in subglacial conduits during conduit enlargement: implications for modeling conduit evolution. Earth Surface Processes and Landforms, 39 (3), 296-310. doi:10.1002/esp.3447

Gulley, J.D., Walthard, P., Martin, J., Banwell, A.F., Benn, D.I. and Catania, G., 2012. Conduit roughness and dyetrace breakthrough curves: why slow velocity and high dispersivity may not reflect flow in distributed systems. Journal of Glaciology, 58 (211), 915-925. doi:10.3189/ 2012JoG11J115

Hagen, J.O., Kohler, J., Melvold, K. and Winther, J.-G., 2003. Glaciers in Svalbard: mass balance, runoff and freshwater flux. Polar Research, 22 (2), 145-159.

Hagen, J.O., Liestøl, O., Roland, E. and Jørgensen, T., 1993. Glacier Atlas of Svalbard and Jan Mayen. Meddelelser Nr. 129 Norsk Polar Institutt, Oslo.

Hjelle, A., 1993. Geology of Svalbard. Norsk Polarinstitutt, Oslo.

Hodgkins, R., 1997. Glacier hydrology in Svalbard, norwegian high arctic. Quaternary Science Reviews, 16, 957973. doi:10.1016/S0277-3791(97)00032-2

Hodgkins, R., 2001. Seasonal evolution of meltwater generation, storage and discharge at a non-temperate glacier in Svalbard. Hydrological Processes, 15, 441-460. doi:10.1002/hyp.160

Hodgkins, R., Tranter, M. and Dowdeswell, J.A., 2004. The characteristics and formation of a High-Arctic proglacial icing. Geografiska Annaler: Series A, Physical Geography, 86 (3), 265-275. doi: 10.1111/j.0435-3676.2004 $.00230 . x$

Hooke, R.L., 1989. Englacial and subglacial hydrology: a qualitative review. Arctic and Alpine Research, 21 (3), 221-233.

Hubbard, B., Tison, J.-L., Janssens, L. and Spir, B., 2000. Ice-core evidence of the thickness and character of clear facies basal ice: Glacier de Tsanfleuron, Switzerland. Journal of Glaciology, 46 (152), 140-150. doi: 10.3189/ 172756500781833250

Humlum, O., Elberling, B., Hormes, A., Fjord, K., Hansen, O.H. and Heinemeier, J., 2005. Late-Holocene glacier growth in Svalbard, documented by subglacial relict vegetation and living soil microbes. The Holocene, 15 (3), 396-407.

Irvine-Fynn, T.D.L., Hodson, A.J., Moorman, B.J., Vatne, G. and Hubbard, A.L., 2011. Polythermal glacier hydrology: a review. Reviews of Geophysics, 49 (RG4002), 1-37. doi:10.1029/2010RG000350

Jacob, T., Wahr, J., Pfeffer, T.W. and Swenson, S., 2012. Recent contributions of glaciers and ice caps to sea level rise. Nature, 482 (7386), 514-518. doi:10.1038/ nature 10847

Kamb, B., 1987. Glacier surge mechanism based on linked cavity configuration of the basal water conduit system. Journal of Geophysical Research, 92 (B9), 9083-9100. doi: 10.1029/JB092iB09p09083

Liestøl, O., 1976. Pingos, springs, and permafrost in Spitsbergen. In Norsk Polarinstitutt Arbok. 7-29.

Lorrain, R., Sleewaegen, S. and Fitzsimons, S., 2002. Ice formation in an Antarctic glacier-dammed lake and implications for glacier-lake interactions. Arctic, Antarctic, and Alpine Research, 34 (2), 150-158. doi:10.2307/ 1552466

Lovell, H., Fleming, E.J., Benn, D.I., Hubbard, B., Lukas, S. and Naegeli, K., in review. Former dynamic behaviour of 
a cold-based valley glacier on Svalbard revealed by structural glaciology and basal ice investigations. Journal of Glaciology.

Lukas, S., Benn, D.I., Boston, C.M., Brook, M., Coray, S. Evans, D.J.A., Graf, A., Kellerer-Pirklbauer, A., Kirkbride, M.P., Krabbendam, M., Lovell, H., Machiedo, M., Mills, S.C., Nye, K., Reinardy, B.T.I., Ross, F.H. and Signer, M., 2013. Clast shape analysis and clast transport paths in glacial environments: a critical review of methods and the role of lithology. Earth-Science Reviews, 121, 96-116. doi: 10.1016/j.earscirev.2013.02.005

Mair, D., Willis, I., Fischer, U.H., Hubbard, B., Nienow, P. and Hubbard, A., 2003. Hydrological controls on patterns of surface, internal and basal motion during three spring events: Haut Glacier d'Arolla, Switzerland. Journal of Glaciology, 49 (167), 555-567. doi:10.3189/ 172756503781830467

Mavlyudov, B.R., 2005. About new type of subglacial channels, Spitsbergen. In: Mavlyudov, B.R. (ed.), Glacier Cave and Glacial Karst in High Mountains and Polar Regions. Institute of Geography of the Russian Academy of Sciences, Moscow. 54-60.

Mavlyudov, B.R., 2006. Internal drainage systems of glaciers (in Russian), Moscow. 395 p.

Nienow, P., Sharp, M. and Willis, I., 1996. Temporal switching between englacial and subglacial drainage pathways dye tracer evidence from the Haut Glacier d'Arolla Switzerland. Geografiska Annaler: Series A, Physical Geography, 78 (1), 51-60. doi:10.2307/521134

Pfeffer, T.W., Harper, J.T. and O’Neel, S., 2008. Kinematic constraints on glacier contributions to 21 st-century sealevel rise. Science, 321, 1340-1343. doi:10.1126/ science.1159099

Pulina, M. and Rehak, J., 1991. Glacier caves in Spitsbergen. In: Eraso, A., (ed.), 1st International Symposium of Glacier Caves and Karst in Polar Regions. Madrid. 93-117.

Radić, V. and Hock, R., 2011. Regionally differentiated contribution of mountain glaciers and ice caps to future sea-level rise. Nature Geoscience, 4 (2), 91-94. doi:10.1038/NGEO1052
Röthlisberger, H., 1972. Water pressure in intra- and subglacial channels. Journal of Glaciology, 11 (62), 713.

Röthlisberger, H. and Lang, H., 1987. Glacial hydrology. In Gurnell, A.M. and Clark, M.J. (eds), Glacio-fluvial Sediment Tansfer: An Alpine Perspective. John Wiley \& Sons Ltd, Chichester, West Sussex. 37-44.

Shreve, R.L., 1972. Movement of water in glaciers. Journal of Glaciology, 11 (62), 205-214.

Stuart, G., Murray, T., Gamble, N., Hayes, K. and Hodson, A.J., 2003. Characterization of englacial channels by ground-penetrating radar: An example from Austre Brøggerbreen, Svalbard. Journal of Geophysical Research, 108 (B11), 1-13. doi:10.1029/2003JB002435

Temminghoff, M., 2009. Characterization of the englacial drainage system in Scott Turnerbreen, Svalbard, by speleological mapping and ground-penetrating radar. MS diss., Department of Geology, The University Centre in Svalbard (UNIS), Norway \& Department of Geography, Ruhr-Universität Bochum, Germany.

Tranter, M., Brown, G.H. Hodson, A.J. and Gurnell, A.M., 1996. Hydrochemistry as an indicator of subglacial drainage system structure: a comparison of alpine and sub-polar environments. Hydrological Processes, 10, 541-556.

Vatne, G., 2001. Geometry of englacial water conduits, Austre Brøggerbreen, Svalbard. Norwegian Journal of Geography, 55 (2), 85-93. doi:10.1080/713786833

Van Hoof, K., 2008. Characterization of englacial conduits in Longyearbreen, Svalbard, by speleological mapping and ground-penetrating radar. MS diss., Department of Geology, The University Centre in Svalbard (UNIS), Norway \& Department of Geology and Soil Science, Unversiteit Gent, Belgium.

Walder, J.S. and Fowler, A., 1994. Channelized subglacial drainage over a deformable bed. Journal of Glaciology, 40 (134), 3-15. 